\title{
RUPTURA E INTEGRAÇÃO: O CASO DA INTERVENÇÃO DO PASEO DE LA BRECHA NO CASCO FUNDACIONAL DE COLÔNIA DO SACRAMENTO, URUGUAI
}

\author{
Autor: Maria Inés Travieso Rios; Luiz Eduardo Fontoura Teixeira \\ Universidade Federal de Santa Catarina \\ Director de la tesis en curso: Margarita Nilda Barretto Angeli, Phd \\ EMail: mariainesrios.cult@gmail.com
}

\begin{abstract}
RESUMO
Aborda o estudo de caso do Casco Fundacional de Colônia do Sacramento enfocando as transformações territoriais e de significado urbano, no contexto da chancela da UNESCO como Patrimônio da Humanidade. Cidade-documento, Colônia demonstra sua importância como território estratégico no controle do continente sul americano nos séculos XVII e XVIII. De cidadela portuguesa, depois Barrio Sur e chegando ao atual Bairro Histórico, teve alterações de valor e percepção urbanos no decorrer do tempo. Como recorte do estudo é problematizado o projeto Paseo de La Brecha e sua interferência no contexto patrimonial. Na escala urbana provoca uma ruptura na estrutura fundiária tradicional conectando duas ruas. Na escala do objeto propõe uma arquitetura contemporânea, em tensão com a paisagem patrimonial. Através de pesquisa bibliográfica e iconográfica, depoimentos de técnicos e demais atores, se estuda o impacto na vida cotidiana e no turismo cultural das mudanças provocadas no território delimitado pela antiga muralha.
\end{abstract}

Palavras-chave: Patrimônio da Humanidade, turismo cultural, intervenção urbana, Colônia do Sacramento.

\begin{abstract}
It addresses the case study of the Founding Hull of Colonia del Sacramento focusing on territorial transformations and urban meaning, in the context of UNESCO's seal as a World Heritage Site. Citydocument, Colonia demonstrates its importance as strategic territory in the control of the South American continent in the XVII and XVIII centuries. From Portuguese citadel, then Barrio Sur and arriving at the current Historic District, had changes of urban value and perception over time. As a study cut, the Paseo de La Brecha project and its interference in the patrimonial context are problematized. In the urban scale it causes a rupture in the traditional land structure connecting two streets. In the scale of the object proposes a contemporary architecture, in tension with the patrimonial landscape. Through bibliographical and iconographic research, testimonies of technicians and other actors, one studies the impact on daily life and cultural tourism of the changes provoked in the territory delimited by the old wall.
\end{abstract}

Key words: World Heritage Site, cultural tourism, urban intervention, Colonia del Sacramento. 


\section{INTRODUÇÃO}

Quais as possíveis transformações, territoriais e culturais, que a distinção da UNESCO, instrumentalizada pelo agente turismo, pode provocar numa cidade que detém um território patrimônio da humanidade? $O$ presente estudo surge como um recorte da pesquisa feita para a elaboração da dissertação de mestrado da autora e das leituras propostas pelo professor responsável pelo seu estágio de docência na disciplina "Arquitetura Latino Americana". A partir das reflexões acerca do questionamento inicial, suas investigações perseguem indícios das modificações identitárias e espaciais decorrentes da relação entre patrimônio e turismo cultural em um território patrimônio da humanidade. O sítio, o Casco Histórico de Colônia do Sacramento e suas bordas detém reconhecido valor pela sua excepcional integração entre os estilos arquitetônicos português, espanhol e pós-colonial. Esse possui subsídios documentais de duas décadas, desde sua distinção em nível mundial, fato preponderante na sua escolha como caso de estudo para a dissertação. Por meio de pesquisa bibliográfica, inicialmente buscou-se o entendimento de como se deu a relação do Uruguai com o turismo e com o seu patrimônio histórico-cultural desde a passagem para 0 século XX, culminando com a fundação da Comisión Nacional del Turismo em 1930, até este ser reconhecido como principal atividade econômica do país em 2016. Para desvelar quais foram as principais transformações e sua reverberação na forma como que as pessoas se relacionam com o espaço, foram investigados três momentos distintos dos ciclos históricos do sítio. Partiu-se da primeira parte do século passado, quando o assim denominado "Barrio Sur" ainda estava à margem da expansão da cidade e de sua sociedade. A seguir estudou-se um período intermediário desde os anos de 1960 quando se iniciaram os projetos de arqueologia urbana e as obras de reconstrução da muralha. Ressalte-se que, ainda em 1971, foi criada a Comisión del Patrimonio Artístico Histórico Cultural de la Nación. Finalmente abordou-se o período pós chancela, quando o sítio passou de um patrimônio local para o âmbito mundial. Neste último cenário está inserido o projeto Paseo de La Brecha. O primeiro contato com o recorte aqui proposto ocorreu, ainda em sua etapa de obra (2016), em visita a cidade por motivo do Seminário Internacional de Turismo e Patrimônio realizado em Colônia do Sacramento. Num território de paisagem singular como é o caso do Bairro Histórico, a inserção de um projeto contemporâneo induz à reflexão acerca da possibilidade e da complexidade de intervir num sítio Patrimônio da Humanidade. Metodologicamente, se partiu das leituras conceituais, levantamento documental e bibliográfico para problematizar o projeto. Porém, apesar de seu reconhecimento nacional e internacional, ainda são poucas as publicações acadêmicas referentes ao projeto. Desta forma, o contato com o escritório de arquitetura responsável pela autoria se fez necessário. Isso para compreender como se deram as negociações com os órgãos responsáveis, a aprovação da UNESCO frente às modificações na paisagem urbana decorrentes da implantação do projeto e a experiência de coordenação de uma equipe multidisciplinar. Tais peculiaridades configuram o partido arquitetônico-urbano adotado e sua morfologia, determinando como a proposta se relacionaria com o espaço. Por meio de uma arquitetura contemporânea singular, que aposta na relação entre patrimônio e turismo cultural, já presente no sítio onde está inserido, o Paseo de La Brecha é uma intervenção que propõe a diversificação de atividades no intuito de valorizar e qualificar o espaço respeitando sua significância histórica e cultural. Além disso, o projeto, através de uma ruptura com a estrutura fundiária fundacional, introduz o conceito de "galeria", reinterpretando essa categoria de passagem urbana, advinda do século XIX. Isso caracterizaria uma dupla qualidade da intervenção, a da nova inserção urbana, acompanhada por uma arquitetura que se insere, de forma atual, entre as edificações pretéritas.

\section{COLÔNIA DO SACRAMENTO}

Para compreender a fisionomia do Bairro Histórico de Colônia do Sacramento se faz necessário rever algumas particularidades históricas que refletiram na forma como a cidade foi se apropriando do território a partir do núcleo fundacional. A trama de ruas intrincadas, as construções na sua maioria de um pavimento, a muralha perimetral iniciada na beira do rio, a adequada distribuição das construções e o aproveitamento das barreiras naturais do lugar são características da apropriação da topografia e da paisagem natural para fins fundacionais da colonização portuguesa. Porém o sítio apresenta uma forte influência na sua paisagem arquitetônica das duas coroas, a Portuguesa e a Espanhola, que foram se dando de forma alternada. Este fato é citado no Plan de Gestión del Barrio Histórico de Colonia del Sacramento como uma das características de sua distinção e reconhecimento pela UNESCO como Patrimônio da Humanidade desde 1995 (PGBHCS, 2012:34). Num breve levantamento cronológico se pode observar que inicialmente os períodos de domínio de uma coroa ou outra se dão em pequenos intervalos temporais. Isso se percebe nas marcas deixadas no sítio de grande carga patrimonial. Este fato se deve à relevante importância desta região, lugar protegido dos ventos com uma situação geopolítica estratégica. Era um porto seguro na foz do Rio da Prata, descrito pelos historiadores como a principal forma de escoamento de mercadorias do interior do continente sul-americano dos séculos XVI a XVIII. No território era marcante a presença dos nativos do 
grupo étnico pampeano, que se dedicavam à caça do gado nativo do qual retiravam o couro para venda nas margens do rio (Cortesão, 1954). Este panorama junto à indefinição da linha de Tordesilhas fez surgir a necessidade de demarcar e dominar este território. Fatos que propiciaram a fundação em 20 de janeiro de 1680 por Portugal, da Colônia do Sacramento, na chamada Terra Firme de São Gabriel (Figura 01).

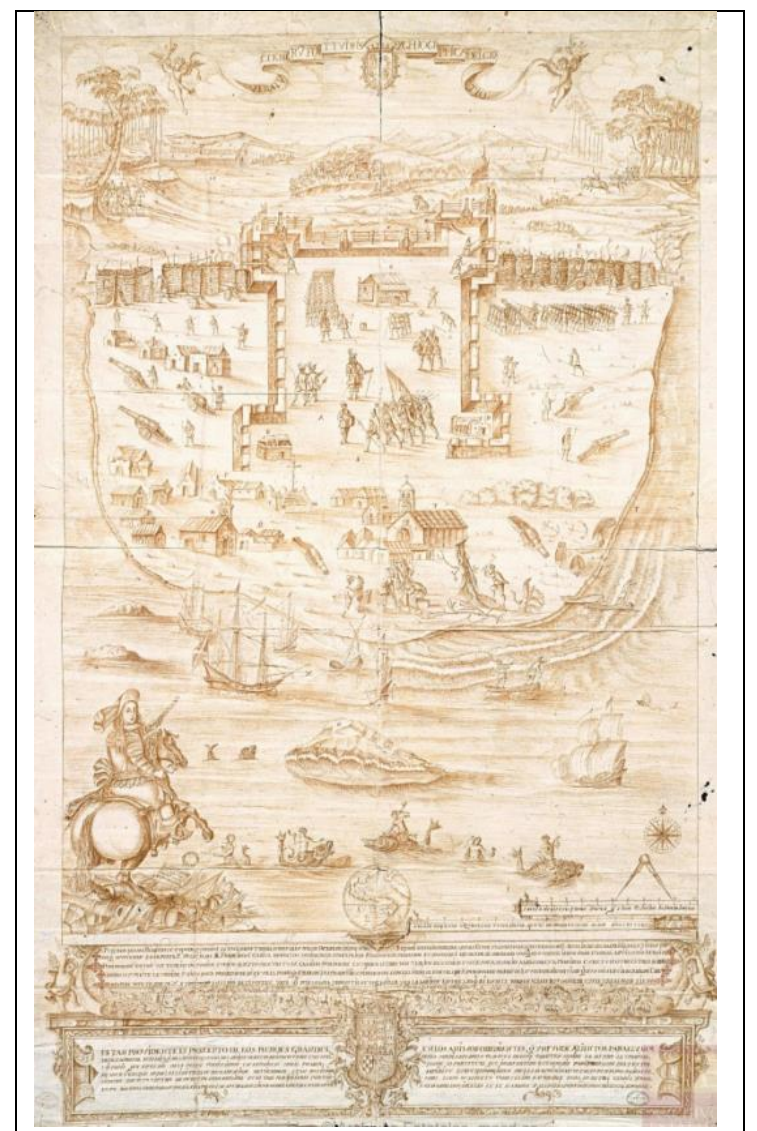

Fig. 01: Planta da Praça-Forte da Colônia do Sacramento (1681)

(Bernardo Antonio de Meza, Archivo General de Indias, España)

Manuel Lobo desembarcou na ilha de São Gabriel e iniciou os alicerces e as primeiras construções da Fortaleza del Santísimo Sacramento na península à beira do rio da Prata. Alguns "ranchos" para civis configuraram a Nova Colônia Lusitana. Mas já em agosto do mesmo ano, José Garro (então governador de Buenos Aires) invadiu Colônia num episódio relatado como um verdadeiro massacre. Em 1681, por meio do tratado conhecido como Provisório, foi determinada a devolução de Colônia a Portugal. Assim a partir de 1683 uma nova população se instalou, surgindo a chamada Nova Colônia do Santíssimo Sacramento. Francisco Naper de Lencastre foi nomeado governador, construindo fortificações e casas de alvenaria. O sítio neste período inicial era uma zona de ocupação portuguesa que se estendia com grande prosperidade ao redor da praça-forte. Ali poderiam ser vistas casas, quintas, propriedades rurais, jardins e zonas de plantio (Larriqueta, 1996). É importante relatar esta ambiência urbana e as posteriores inovações, para compreender a importância da muralha naquele tempo, como um elemento fundamental na proteção da cidadela. Entre 1695 e 1699 a primeira Igreja Matriz foi erguida, e um período de estabilidade se instalou no território até 1705, quando o governador de Buenos Aires Alonso de Valdés Inclán, ao invadir Colônia ordenou sua demolição, executada no mesmo ano. Posteriormente via tratado de Amistad y Paz entre Espanha e Portugal se reconheceu a soberania lusitana sobre Colônia. A cidade era essencialmente um lugar de comércio muito lucrativo, uma praça com caráter cosmopolita, confluência de várias nacionalidades. Na sua trajetória foi tornando-se ponto de atração no extremo sul brasileiro para os cariocas, dentre eles comerciantes, escravocratas e especuladores (Santos, 2001). Em 1745, sob o domínio português, são claras as obras de melhorias das muralhas e das fortificações na terra firme. Assim o novo pórtico de pedra lavrada foi inaugurado como portão principal. Leva o brasão de armas de Portugal e sob ele, encontra-se em linguagem barroca, a seguinte inscrição: "REINANDO EL REY D. JOAO V.N.S.IANNO 1745" (PGBHDS, 2012:36). As alternâncias de poder na cidade continuaram, deixando as marcas das transformações em seu território, em 1762 (Espanha), 1763 (Portugal), 1777 (Espanha), 1807 (Ingleses). A Brecha onde se encontra o objeto de nosso estudo, foi um ponto vital para a defesa do território (Figura 02). Assim se pode compreender a relevância dos vestígios da muralha. Nas escavações da primeira etapa de 
implantação do projeto Paseo de La Brecha, foram encontradas aproximadamente trezentas peças arqueológicas de diferentes tempos históricos. São em parte indígenas, outras da ocupação portuguesa, do período espanhol e do período inglês. Foram resgatadas cerâmicas portuguesas do século XVII, espanholas do século XVIII e inglesas do século XIX. Também foram encontrados elementos militares, como, balas de canhões, fivelas de diferentes uniformes militares e pedras trabalhadas pelos índios. As tropas espanholas colocavam os indígenas à frente em seus confrontos e não lhe davam armamentos. Assim usavam utensílios próprios, como as pedras que eram amarradas em um pedaço de couro e lançadas contra o inimigo. Também foram encontrados muitos elementos da vida cotidiana, sendo a grande maioria objetos militares. Como a cidade forte estava localizada numa península, para atacar a fortaleza se desembarcava na baía, fazendo trincheiras. Efetuavam ataques contra a muralha da fortaleza que aproximadamente tinha nove metros de altura e uma espessura de três a quatro metros. O local onde se atacava e se abria "la brecha" na muralha era o exato lugar onde foram feitas as escavações do projeto. Uma vez que os canhões que atacavam a fortaleza derrubavam um pedaço da muralha a isto se chamava abrir uma "brecha". Os militares que vinham a pé poderiam invadir a fortaleza (este fato explica a quantidade de objetos encontrados das vestimentas dos soldados). Neste momento havia duas possibilidades: ou ocupavam a fortaleza por meio de rendição, ou se produziam os combates. Assim a cada batalha se reconstituía a muralha, repetindo ciclicamente a mesma situação após outros ataques.

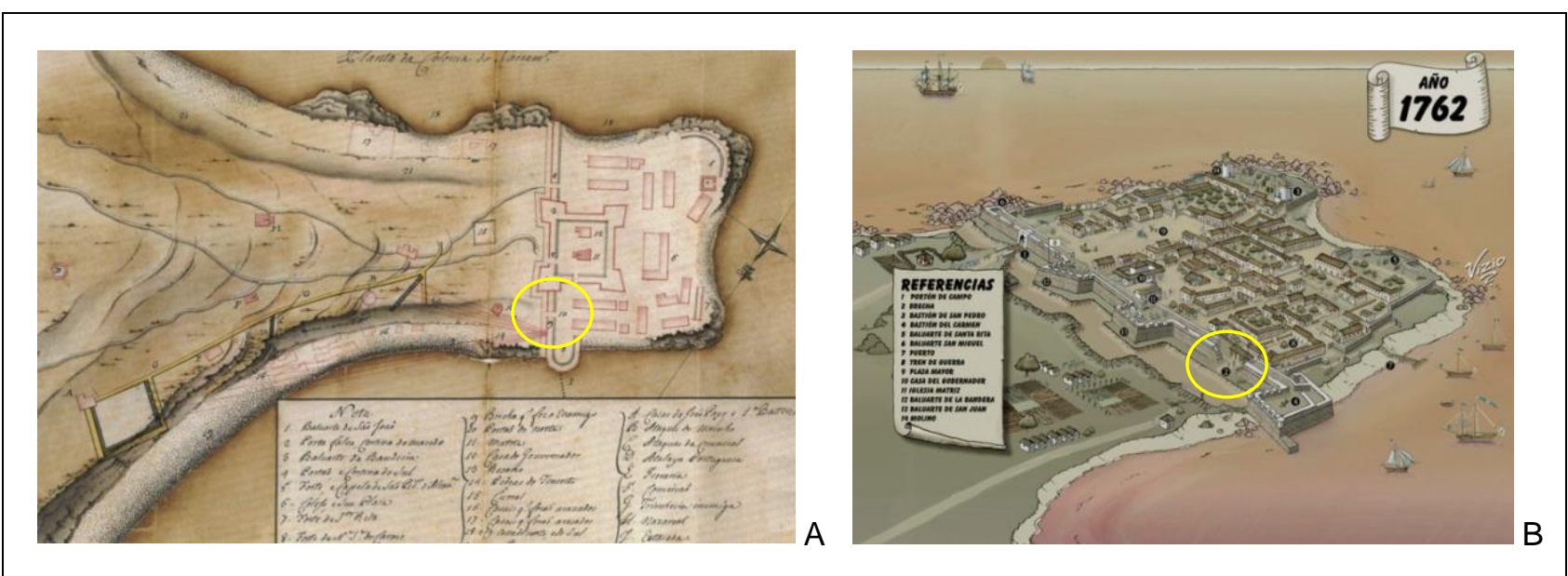

Fig. 02: Localização da "Brecha" no Sistema Defensivo da Colonia del Sacramento, A (1736) e B (1762)

Elaboração própria a partir das plantas: A (autor anônimo, Arquivo Histórico do Exército, Brasil) e B (FRAZZI ARQUITECTOS - Arq. Matías Frazzi)

Nas primeiras três décadas do século XIX, o Uruguai se configurou como uma Nação. Este sentimento se refletiu na necessidade de uma nova linguagem arquitetônica e urbana. Em Colônia este anseio foi marcado pela possibilidade de uma expansão urbana extra muralha.

\section{A RELAÇÃO ENTRE AS MALHAS PORTUGUESA E ESPANHOLA}

"Considerando completamente inútiles para la defesa del Estado las fortificaciones de la ciudad de la Colonia, del lado Este, em dirección Norte a Sur, perjudicándose mas bien como un obstáculo al desarrollo de esa población. (...) el Presidente de la República em acuerdo de Ministros há resuelto y decreta: Art. 1 Los trabajos que han de ejecutarse para la demolición de las murallas, baterías y contraescarpas del recinto de las antiguas fortificaciones al este de la Ciudad de Colonia, principiarán el día 30 del corriente.(...) Art. 5 - Los terrenos que resulten disponibles serán divididos en solares y vendidos en remate público, vertiéndose su importe en la Tesorería General para sufragar el costo de esa obra" (Decreto, 1859).

Desta forma, em 1859, o presidente da República, D. Gabriel A. Pereira, determinou a integração da parte interna e externa da muralha de Colônia do Sacramento. A ordem foi acompanhada pela ideia de apagar o passado direcionando o crescimento da cidade para além dos seus limites fundacionais. Assim por insistência das classes mais favorecidas, foram derrubadas as muralhas. O agrimensor Victor Delort, inicia o esboço da "nova cidade" nos extramuros (Scirgalea, 2015). Ainda na década de 1860 um trapiche de passageiros é construído, entre outras melhorias que ocorreram no incentivo de uma economia portuária da região. Neste período ainda foi inaugurada a iluminação pública a querosene e o primeiro dique para reparo de embarcações no Rio da Prata. Isso veio a gerar um aumento da população e uma necessária organização em sua expansão urbana. A demarcação espacial da nova cidade surgiu considerando os dois traçados (Figura 03). 


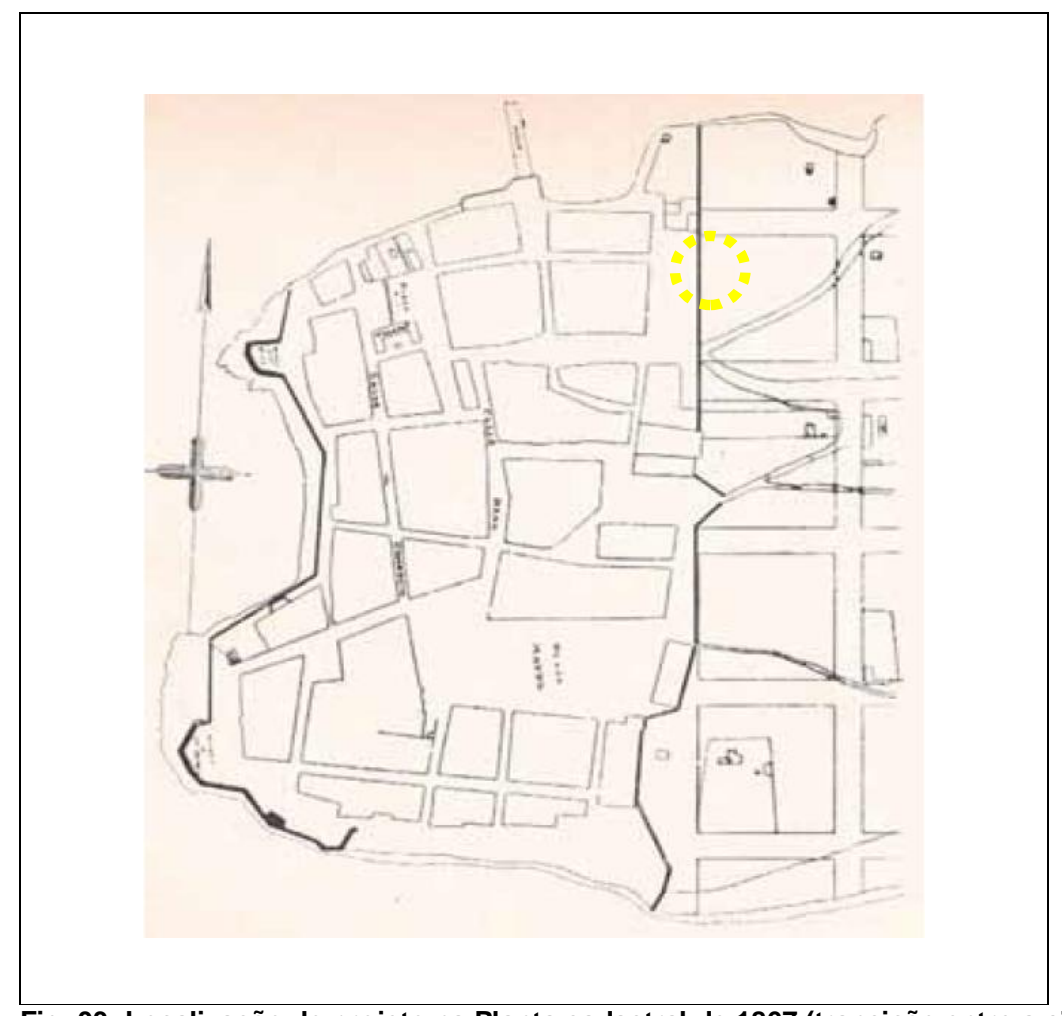

Fig. 03: Localização do projeto na Planta cadastral de 1867 (transição entre a cidade "Vieja" e nova malha) Elaboração própria a partir da planta do Plan de Gestión de Colonia do Sacramento (2012:31)

Nas últimas décadas do século XIX ocorreram vários fatos importantes que colocaram a cidade de Colônia em destaque no cenário nacional e que acabaram refletindo na expansão da nova malha urbana. É relevante citar a instalação do serviço telefônico no Uruguai localizado em Colônia (1880) e a inauguração dos equipamentos de telefonia e telegrafia entre as margens do Rio da Prata por meio de um cabo submarino (1889). Ainda no final daquele século foram pontuadas melhorias nos bairros periféricos ao núcleo fundacional. A Praça 25 de Agosto (1887) surgiu como proposta de renovação, sendo considerada a partir de então a principal praça da cidade. No sentido de promover a integração das duas tramas, unificando o espaço, novas atividades foram propostas para o Bairro Histórico. Um exemplo desta iniciativa foi a implantação da sede do Banco de La República (1892). Porém somente no início do século XX que Colônia do Sacramento se reconheceu como cidade moderna. Os esforços foram ao encontro de uma integração do novo centro, em damero, com a malha inicial de traçado português. Durante as primeiras décadas do século XX, o território do Casco Fundacional da cidade de Colônia era reconhecido como "Barrio Sur". Assim era denominado por seus moradores que fazia referência à localização do bairro em relação à Avenida General Flores (PGBHDS, 2012:25). Em 1918, o então Intendente Municipal Felipe Suárez teve um papel importante neste sentido:

"El ciudadano señor Felipe Suárez (...) inició obras higiénicas y de embellecimiento, que llevados a feliz término colocaron a Colonia entre las primeras ciudades de la República. Causas imprevistas paralizaron aquellas obras, pero de ese esfuerzo queda nuestra hermosa plaza, varias calles adoquinadas, principio de rectificación de otras y calles nuevas y bien conservadas. Edificó y estimuló la edificación urbana y valorizó grandemente la propiedad. El pueblo en manifestación pública llevó el tributo debido a su espíritu emprendedor. La obra está en principio, pero desaparecidas las causas que obstaculizaron su preservación, pronto serán una realidad los deseos del vecindario, que quiere el ensanche, la higiene y el embellecimiento de la Colonia" (Acta de Sesiones de la Junta Econômica de 11/04/1918).

Neste documento se percebe as atuações do senhor Suárez, que propôs uma série de obras urbanas para eliminar o que ele denomina de zona roja (região com grande concentração de prostíbulos). $O$ projeto determinava o alargamento das ruas de acesso ao rio. Para isso, pretendia derrubar as casas existentes no bairro para construir novas. Neste contexto a Avenida General Flores se estendeu até a ponta da península, com a função de unir os dois traçados. Como é possível ver na Planta da Cidade de Colônia de 1927 (Figura 04) toda esta região sofreu uma grande transformação urbana e paisagística. Um rasgo que permitiu uma integração por meio de uma avenida larga e arborizada. Podemos observar ainda nesta planta o 
quarteirão no qual atualmente foi implantado o Projeto do Paseo de La Brecha, constatando a presença nesta região do Bairro Histórico das marcas profundas deste processo de modernização da cidade.

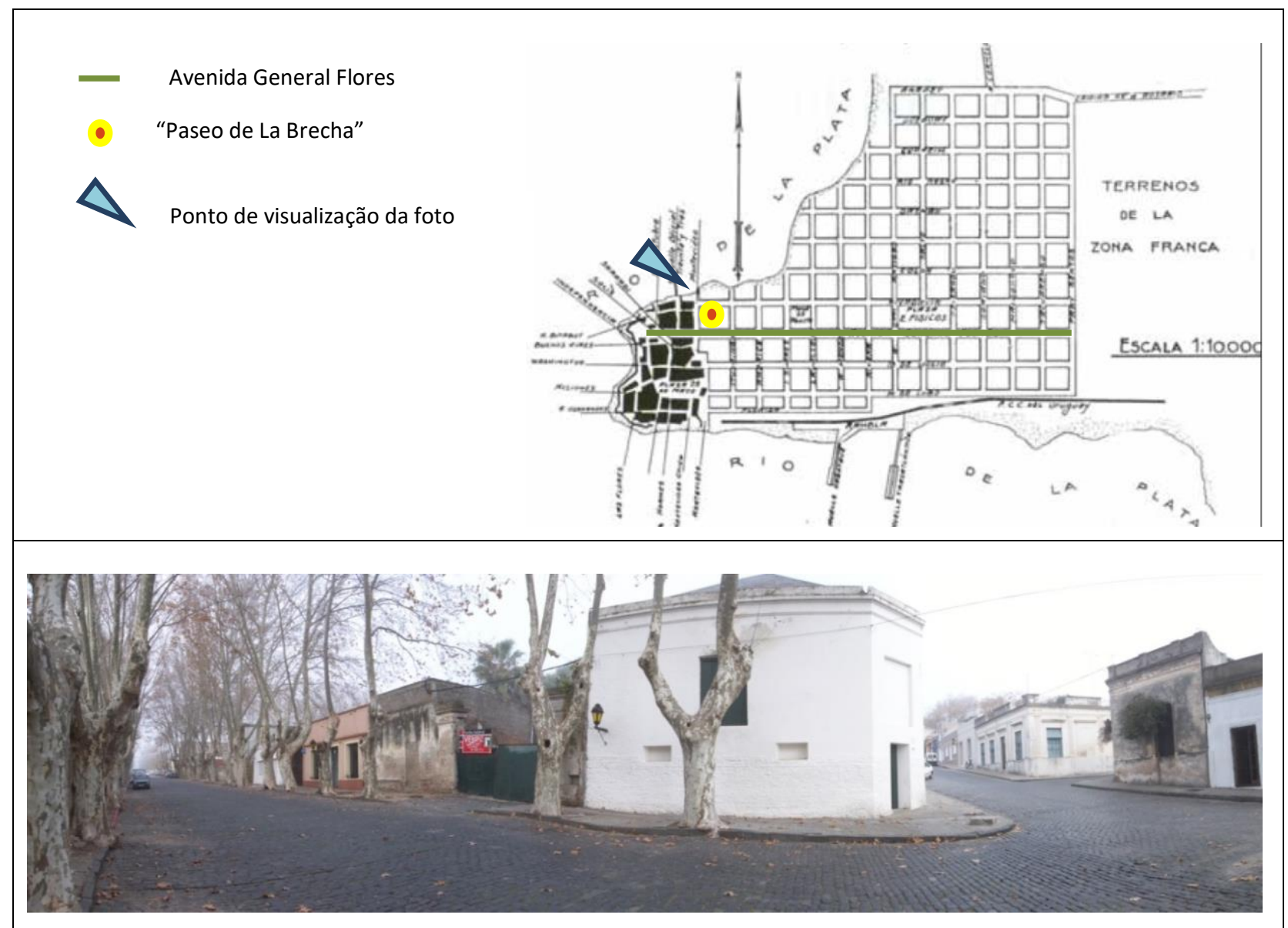

Fig. 04: Planta da Cidade de Colonia (1927), com a localização da Avenida General Fores e Paseo de La Brecha; vista atual do espaço urbano no entorno do projeto

Elaboração própria a partir da planta do Plan de Gestión de Colonia do Sacramento (2012:32); foto: Federico Kulekdjian para FRAZZI ARQUITECTOS

É importante destacar o caráter marginal de alguns povoados que se consolidaram neste período, no Departamento de Colônia, fato que direcionou e impulsionou a expansão urbana das colônias. No caso da cidade de Colônia do Sacramento o núcleo urbano de Real de San Carlos foi um decisivo protagonista como satélite da cidade muralha.

"La clase alta coloniense ha concretado en el ámbito realense (moradores do bairro Real de San Carlos N.A.) sus planes modernizadores - por disponer de mayores espacios e infraestructura - especialmente en lo referido al turismo"(Scirgalea, s/a).

A implantação do hipódromo no complexo Mihanovich e o surgimento e valorização dos balneários trouxeram um uso turístico recreativo ao Real de San Carlos. Mais tarde o povoado se tornará um importante bairro da cidade de Colônia, motivo de orgulho de sua sociedade fato que definitivamente transforma o cenário social da cidade. Com a expansão da cidade, se alterou a dinâmica social e econômica. Isso demarcou o surgimento de uma nova classe social vinculada a esta recente realidade espacial. Neste momento o Barrio Sur ficou à margem da cidade em expansão.

\section{INTERVENÇÕES HISTÓRICAS E CONDICIONANTES ATUAIS}

Nas sucessivas décadas do século XX as crises econômicas acabaram por proteger o Bairro Histórico no sentido de preservar o casario evitando mais intervenções. A partir de 1968 iniciaram os trabalhos do arquiteto Miguel Ángel Odriozola Odriozola, quando se iniciou um período de valorização e resgate do Casco Histórico. 
"verdad, belleza y vida" (Amándola, 2012)

Na sua busca por uma metodologia de ação que permitisse a salvaguarda do bem patrimonial, estes são os três elementos que fundamentaram o trabalho deste importante personagem do Bairro Histórico no século XX. Foi pioneiro, com estudos detalhados iniciados num cenário social bem diferente do que encontramos hoje. Buscou em seu trabalho respeitar as particularidades de cada ponto do casco histórico. $\mathrm{O}$ arquiteto Miguel Ángel Odriozola Odriozola já defendia a reversibilidade da intervenção na arquitetura. Reconhecia que as transformações e a presença da nova arquitetura eram inevitáveis por ser a cidade para ele um organismo vivo. Era claro que Colônia do Sacramento neste sentido não seria uma exceção. Desde suas primeiras intervenções no Bairro Histórico sua maior preocupação era que se pensasse em todos os componentes do sistema urbano. Defendia uma "gestão" minuciosa onde fossem respeitadas as particularidades e singularidades de cada unidade isoladamente, assim como sua representatividade no conjunto.

"desde que se encontraram las primeras trazas de la muralla de la ciudad colonial, com la criación del Consejo Ejecutivo Honorario (desde 1968) capaz de catalogar, clasificar y ordenar las ideas (gestión), y con el generoso y nunca suficientemente agradecido aporte y legado del Arq. Miguel Ángel Odriozola Odriozola. (...) Seguramente no habrán sido fáciles aquellas deciciones de expropiación tomadas por los años 70 s, luego del hallazgo de la muralla que atravesaba el catastro de entonces (que no el original ni tampoco el actual), varios padrones con viviendas construidas y habitadas. Luego, realizar los trabajos de demolición de esas construcciones para la puesta en valor de la muralla encontrada, resolviendo además los critérios de la reconstruccíon o el reacomodo de la nueva situación catastral generada" (Odriozola Guillot, 2011:06).

Fazendo referência às dificuldades encontradas pelo seu pai, o arquiteto Miguel Angel Odriozola Guillot, no texto acima, constatou a necessidade de condicionantes normativas para intervir no âmbito do urbano num sítio como o Casco Fundacional, tombado como Patrimônio da Humanidade. As normativas vêm ao encontro da salvaguarda do bem patrimonial seja ele na escala do objeto, da edificação ou urbana. $O$ fato de propor a unificação de dois lotes (como veremos na proposta do projeto de La Brecha) poderia gerar uma "barra" onde não havia esta barreira. Neste caso a "proibição" do amembramento dos lotes surgiu para que possa permanecer visível a estrutura fundiária original e impedir novas volumetrias impactantes.

\subsection{Primeira etapa}

O cenário inicial que o cliente Sr. Mariano Martínez apresentou aos arquitetos Matías Frazzi y José María Abella proporcionava a possibilidade ímpar de intervir num território Patrimônio da Humanidade. Com dois lotes muito interessantes no Casco Histórico de Colônia do Sacramento a vinte metros do rio e com uma série de condimentos especiais para o que é desenvolver um projeto. Configuraram-se duas saídas para ruas distintas de um mesmo quarteirão, num formato de "L". Um desnível de 2,20 metros entre uma rua e outra, característica que sugeriu aos arquitetos, desde o início, um passeio acompanhando a topografia do sítio. Num dos lotes ainda existia um galpão com aproximadamente 130 anos. Esta era a realidade no início do projeto. De fato antes das escavações não se sabia da real excepcionalidade do sítio onde se estava intervindo, principalmente no que se refere à parte arqueológica. Em abril de 2012, foi o primeiro contato com a Oficina de Patrimônio do Uruguai que está localizada na cidade de Colônia do Sacramento. Desde a proposta inicial apresentada (diferente do projeto final) e à medida que foi avançando, se buscou um trabalho em conjunto com a Oficina de Patrimônio. Com reuniões que buscavam progredir em consenso, à medida que se avançava, surgiam novas normas a serem implementadas. Da ideia inicial até que foram aprovadas as plantas e que de fato se iniciaram as escavações se passaram dois anos e meio. Num trabalho em conjunto com a Oficina do Patrimônio, o escritório cuidava da parte da proposta e a Oficina da parte das normatizações junto a UNESCO. A primeira negociação foi exatamente com o órgão da UNESCO, se referindo ao fato de existirem dois lotes, um com saída para rua com frente à Rua Virrey Ceballos s/n e o outro com frente à Rua Rivadavia № 208. Como já foi citada, a intenção inicial foi unificar os lotes para obter um passeio que pudesse ser visitado. Isso resultou num espaço semi-público com entrada e saída pelas duas ruas. A UNESCO em sítios que são Patrimônio da Humanidade, proíbe unificar parcelas principalmente num caso como este, onde o Casco Urbano é o elemento tombado. Desta forma foi proposta a permissão deste amembramento para criar uma unidade no projeto, ainda que legalmente sejam duas unidades. Para a Oficina do Patrimônio do Uruguai resultava muito interessante essa situação que um projeto privado pudesse pensar no semi-público, ou seja, o projeto surge como uma continuidade da cidade. Com a aprovação da primeira etapa, que incluía os projetos da escavação das bases estruturais e das instalações sanitárias, a obra foi iniciada. A Oficina de Patrimônio e a UNESCO nesses sítios urbanos exigem a participação de um arqueólogo para viabilizar as escavações. Assim a arqueóloga Jacqueline 
Geymonat se uniu à equipe. Quando foram feitas as primeiras escavações arqueológicas foram pouco a pouco descobertas as peças arqueológicas. Principalmente se descobriu que e a muralha estava ali e com ela o contraforte e os restos arqueológicos dos quartéis militares que estavam neste lugar. Foi elaborado um informe arqueológico, o que é obrigatório depois das escavações. Assim que as autoridades receberam este informe, avaliaram o valor das descobertas e o projeto teve que ser revisto.

\subsection{Condicionantes do Projeto}

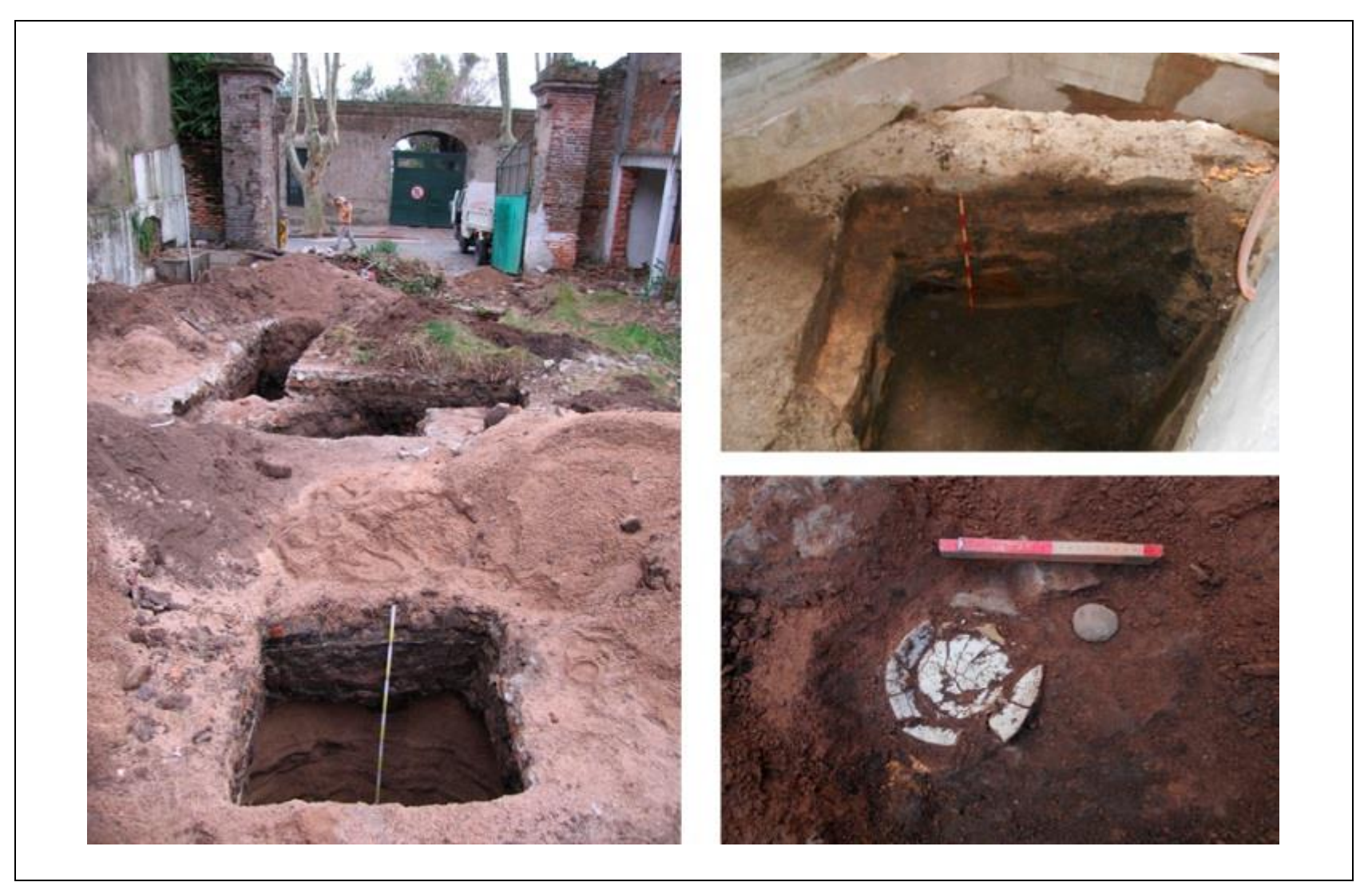

Fig. 05: Escavações (2013)

(FRAZZI ARQUITECTOS - Arq. Matías Frazzi)

Após reformular o projeto e aprovar as novas modificações para iniciar as obras, no setor onde apareceram os restos arqueológicos dos quartéis militares, foi necessário fazer modificações. Justamente neste setor estavam as bases das escadas que dão acesso às habitações do primeiro pavimento. Foram feitas duas sapatas laterais de concreto com uma viga de passagem, para não tocar nos restos dos quartéis que ficaram a vista. No acesso à escada se optou por colocar um vidro transparente para poder observar os restos arqueológicos. Assim pouco a pouco foram surgindo alterações significativas. Em outro setor do projeto foi encontrado o contraforte da muralha da cidadela próxima aonde está localizada a estrutura antiga do galpão de madeira. O contraforte, um muro de pedra que data de aproximadamente de 1800, tem uma espessura de 1,70 metros. Nesta área foram inicialmente projetadas duas unidades habitacionais que estavam dentro do que seria o lote do galpão. Estas habitações no projeto inicial estavam enterradas numa profundidade de 1,20 metros. Ao encontrar o contraforte foi necessário modificar o projeto elevando as habitações em 1,20 metros. Isso por sua vez esbarrava noutra normativa. Ao elevar a habitação se excedia na altura máxima permitida de seis metros. Após expor o resultado espacial que seria gerado com a proposta a Oficina de Patrimônio achou interessante que se pudesse conservar e visualizar o resto arqueológico do contraforte. Permitiu-se que toda a estrutura fosse erguida, e como resultado, os volumes excedem aproximadamente a 1,50 e 1,70 metros da altura máxima permitida pela norma. Um dos pontos interessantes deste projeto é o partido positivo que se tirou das condicionantes. Cada uma das propostas que foram surgindo enriqueceram um projeto que no inicio nasceu como uma simples intervenção imobiliária. A partir deste contexto a arqueóloga ampliou sua participação, estando presente em todas as etapas até o final da obra. Assim o projeto se converteu também em uma proposta que nucleava diferentes situações numa ação multidisciplinar. Com a constatação da relevância do sítio era necessário ter um maior conhecimento acerca da história militar do mesmo, foi sugerida a necessidade da participação do historiador Major Marcelo Días Buschiazzo, especialista nesta temática. Como foi visto, a Cidadela de Colônia surgiu 
como um ponto estrategicamente militar. Além de gerar um projeto de arquitetura, a equipe percebeu que necessitava desse aporte, era um projeto integral com uma relevante importância do ponto de vista arqueológico e histórico. Por fim era necessário expor museologicamente as peças e toda a parte histórica do sítio. Neste momento foi agregado à equipe o museólogo Diego Lascano, especialista em mostras museológicas de elementos militares. Desta forma, o projeto se nutre de diferentes atores ultrapassando a parte comercial e a parte de arquitetura. O passeio que era a intenção primitiva se converteu em um passeio museológico e histórico que alimenta o circuito histórico da cidade.

"Valorar lo que tiene valor" (Giraldi, 2018).

Em suas palavras o arquiteto Álvaro López se referiu ao projeto do Paseo de La Brecha como uma obra singular por sua capacidade de integrar-se ao bairro. Para o arquiteto é necessário discutir as particularidades do sítio e questionar a qualidade das intervenções. Fugindo dos processos de recuperação patrimonial que geram gentrificação, assim ele questiona - onde estão as pessoas no Bairro Histórico? Observar as particularidades de cada unidade que compõe uma paisagem arquitetônica única como a do Bairro Histórico é extremamente necessário para ele, para fugir do perigo de transformá-lo em uma "boutique". Insiste na importância de "um turismo cultural que seja realmente cultural", dando valor ao, que no sítio, o diferencia histórica e culturalmente dos demais. Considerando o patrimônio como um vetor de desenvolvimento local (De Varine, 2013), a valorização das particularidades paisagísticas do sítio permitem uma visão mais crítica das transformações culturais e territoriais que se esperam da relação entre turismo e patrimônio cultural. Choay (2011:36) faz referência à classificação por parte da UNESCO do patrimônio mundial e sua responsabilidade na mercantilização patrimonial.

"En estos procesos de revitalización con o sin gentrificación, orientados o no para el turismo, lo ideal seria que museólogos, arquitectos, urbanistas, historiadores, científicos sociales, turismólogos, y otros, formen equipos multidisciplinares para una planificación integral dentro de la metodologia de la investigación participativa. Esta presupone que los técnicos se involucren como sujetos de la acción, lo que es también uma nueva forma de pensar el turismo en relación a la cultura."(Barretto, 2007:136)

Barretto (2007) em seu capítulo sobre Patrimônio, Gentrificação e Turismo ao abordar, entre outros exemplos, o Bairro Histórico de Colônia do Sacramento chama a atenção para a importância deste outro diferencial do projeto aqui estudado, a atuação de uma equipe multidisciplinar. A intervenção urbana do Paseo de La Brecha apresenta uma clareza conceitual que pode ser considerada como um fruto das especulações de sua qualificada equipe. Este princípio já constava na Carta de Veneza (1964) em seu artigo segundo, quando o documento se refere à restauração dos monumentos (também as obras modestas que tenham com o tempo um significado cultural) como "uma disciplina que reclama a colaboração de todas as ciências e técnicas que possam contribuir para o estudo e a salvaguarda do patrimônio cultural". Trabalhar com uma equipe multidisciplinar num território tombado pela UNESCO dá condições de compreender as particularidades históricas, físicas e culturais do espaço urbano onde está inserido. No caso as investigações, escavações e descobertas históricas levaram a desvelar os restos da muralha e seu contraforte que formavam a antiga fortificação da cidadela criada em 1680. O fato de ficar localizado num importante trecho da muralha - la Brecha - ponto fundamental na defesa da fortificação deram não apenas o nome mas a identidade ao projeto. Em sua essência o projeto cria uma "brecha" na malha urbana criando uma ruptura na estrutura fundiária tradicional com a introdução de uma galeria. Os vestígios encontrados nas escavações, no decorrer do projeto, de alto valor patrimonial, tornaram tangíveis relevantes episódios da historiografia do Bairro Histórico de Colônia do Sacramento trazendo um aspecto museológico ao espaço. Ainda na forma de utilização dos materiais como vidro e aço se buscou deixar claro o tempo da intervenção, na busca da valorização dos vestígios. No contexto urbano a proposta busca dialogar com seu entorno. A partir de uma observação da arquitetura urbana no entorno ao Projeto Paseo de La Brecha se pode observar uma diversidade nas atividades presentes no sítio. Porém numa análise mais detalhada da Planta de Usos de Suelos del Barrio Historico (Figura 06), podemos constatar a quase inexistência de residências, sendo predominante a atividade comercial e de serviços em suas diversas formas de implantação. Nas estratégias de reequilíbrio do Plano de Gestão do Bairro Histórico de Colônia do Sacramento, são apontados dois aspectos que poderiam distorcer a harmonia do desenvolvimento do Bairro Histórico e que necessitam de uma normatização por meio dos órgãos responsáveis pela análise das propostas de intervenção. O primeiro é o decrescimento populacional o que, conforme o plano, poderia estar causando uma perda da qualidade urbana no sítio. Ainda o Plano de Gestão do Bairro Histórico faz a distinção entre o comércio de proximidade, que está desaparecendo, e o comércio e serviços dedicados ao visitante ocasional e ao turista que está demostrando um considerável crescimento. O segundo aspecto citado no plano, se refere ao crescimento da demanda turística do Bairro Histórico. 


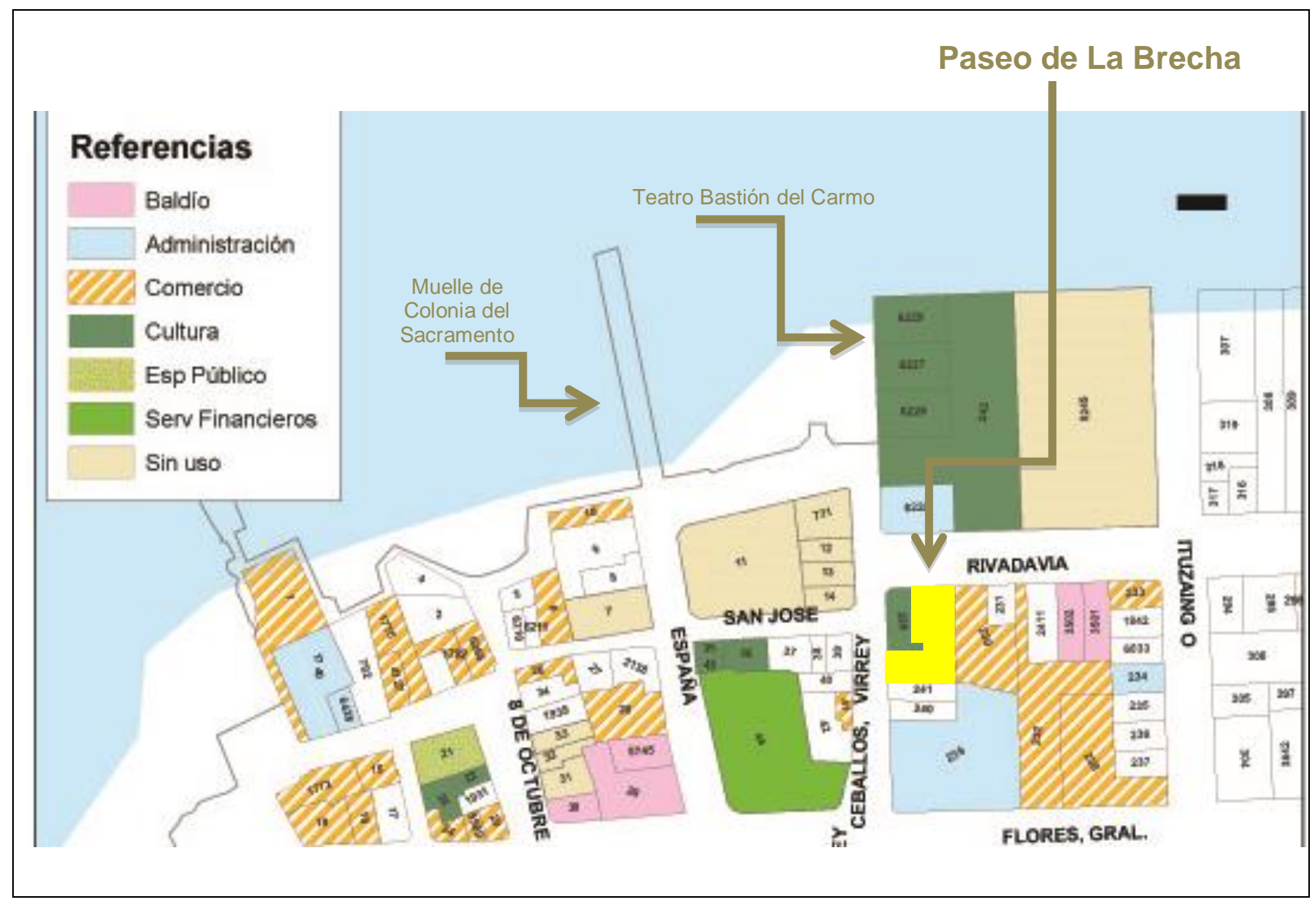

Fig. 06: Localização do projeto e principais pontos de referência na Planta de Usos.

Elaboração própria a partir da Planta de Usos del Suelo (Secretaría de Planeamiento y Ordenamiento Territorial de la Intendencia de Colonia)

É necessário juntar a estes dados o fato da cidade de Colônia do Sacramento ser a principal porta de entrada de turistas argentinos no Uruguai, devido à sua proximidade geográfica com o país vizinho. No terceiro trimestre de 2017 do total de 696.691 visitantes ingressados nos pais, 422.242 eram argentinos (Ministerio do Turismo do Uruguay, 2107). Esta demanda estaria causando um uso excessivo dos espaços públicos assim como uma especialização do comércio local (PGBHCS, 2012:20). No caso da proposta do projeto de La Brecha, estes fatos foram preponderantes nas negociações junto a UNESCO. Pela normatização do Bairro não se permite duas ou mais atividades em uma mesma intervenção. $O$ fato de 0 projeto propor residência e comércio (café) vem a enriquecer a proposta criando diferentes fluxos decorrentes destas atividades. Já a proposta de um museu a céu aberto surge aprimorando o repertório cultural ao longo do percurso proposto ao pedestre, por meio da significância histórica do sítio que juntamente com a forma e uso caracterizam a composição de uma dimensão espacial singular.

\section{O PROJETO PASEO DE LA BRECHA E SUAS PROPOSTAS}

\subsection{Ruptura com a grelha - A galeria urbana}

O projeto nasce com a proposta de criar um novo caminho, uma espécie de ruptura com a malha urbana do casco histórico. Nas palavras dos autores se buscou um "espírito medieval" (Frazzi, 2018). Um circuito com ruas estreitas que vão entrando no seio da cidade. O pedestre então seria convidado a entrar por esta ruela sinuosa o que propicia a descoberta de novas situações. O "Café" surge para dinamizar o espaço, determinando os fluxos do passeio como uma alternativa semi-pública (de um projeto privado) ao espaço público da rua. A percepção do espaço neste contexto é então resultado do todo, dos cheiros, das cores, das texturas, dos pisos, das surpresas, do valor histórico, tudo isso fazendo parte do circuito na perspectiva do pedestre. Este fato foi determinante na abertura deixada na cobertura do antigo galpão. Em uma negociação com a Oficina de Patrimônio, que a princípio defendia o fechamento do espaço, os autores valorizaram o contato com o externo, a conexão com o entorno patrimonial. No térreo (Figura 07) o passeio tem os acessos às residências, ao café e ao circuito histórico-museológico. 


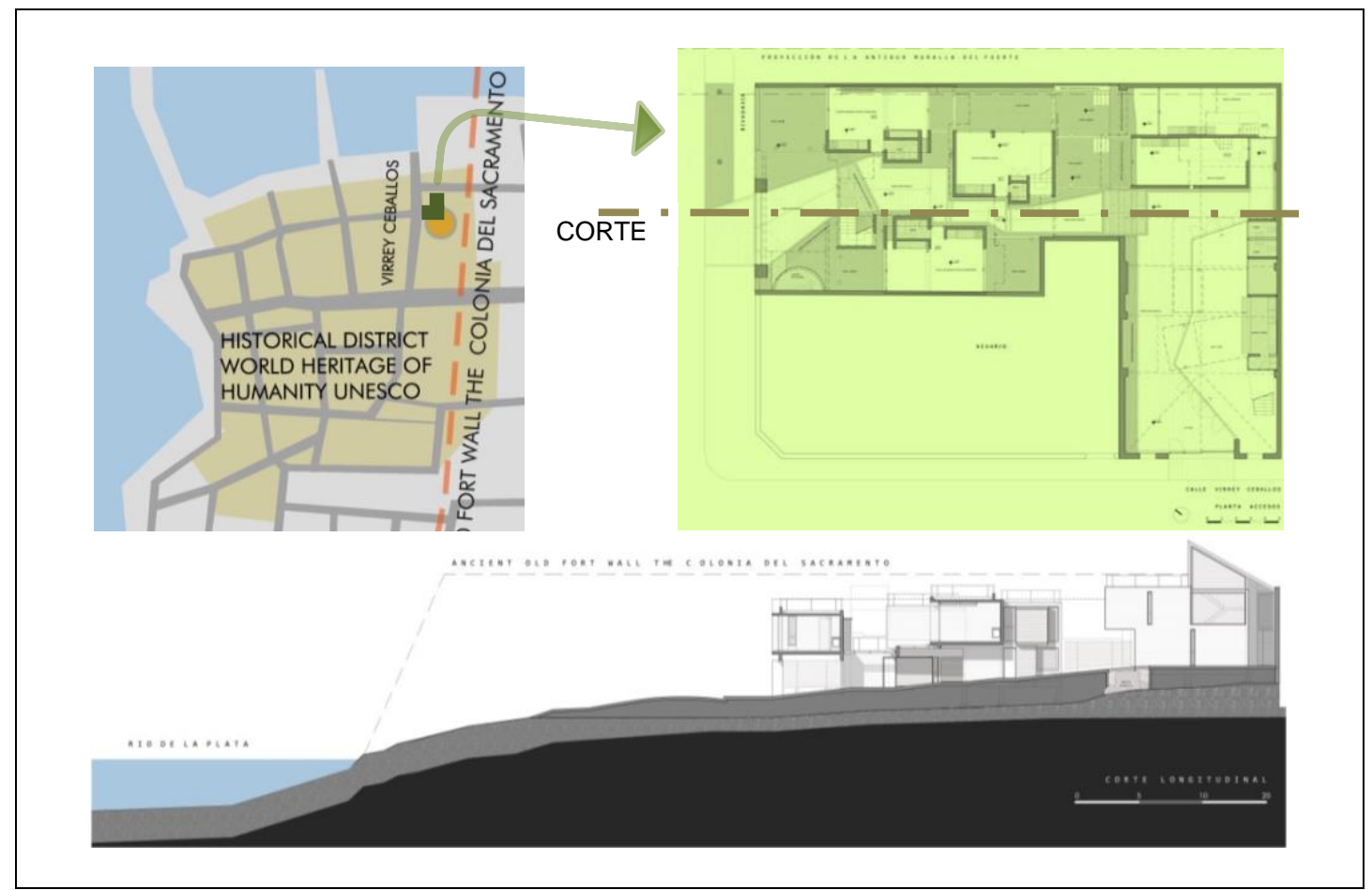

Fig. 07: O passeio na malha urbana, Planta Baixa do Térreo e Corte Longitudinal.

Elaboração própria a partir das plantas do escritório FRAZZI ARQUITECTOS (Arq. Matías Frazzi)

Devido à proximidade do sítio de implantação do projeto da margem do rio, o terreno apresenta um desnível entre os dois lotes (Figura 07). Tirando proveito deste desnível topográfico entre os dois acessos o circuito proposto intra-lote tem um desenho sinuoso que se integra ao percurso original das ruas e vielas. Fazendo referência à herança do urbanismo português presente no Bairro Histórico, com seu desenho acolhedor ao pedestre. Assim existe uma parte que requer certa privacidade, uma segurança no período da noite, apesar da cidade de Colônia ainda ser um lugar relativamente calmo. Desta forma o percurso do passeio ficará aberto durante o dia no horário de funcionamento do café. Os portões envidraçados surgem com a única função de servir de limite físico pela noite no intuito de garantir a segurança da galeria.

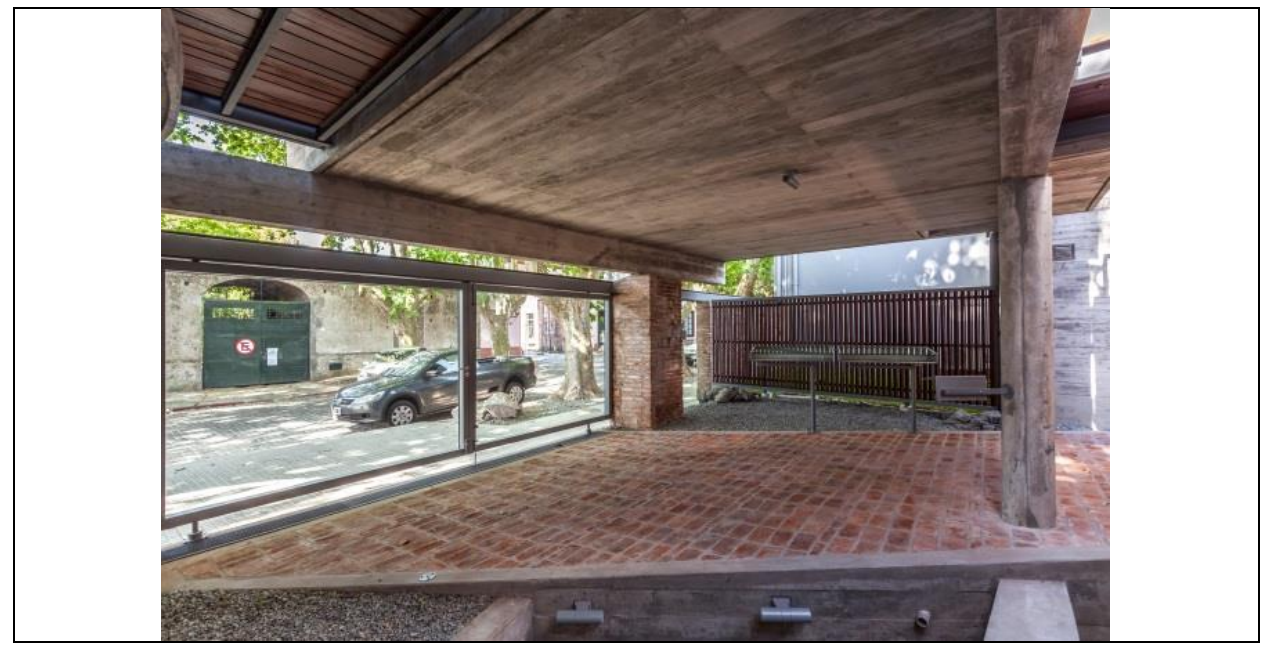

Fig. 08: Detalhe da transparência gerada pelos portões de vidro.

(Federico Kulekdjian para FRAZZI ARQUITECTOS)

As normativas dizem que no Casco Histórico nas fachadas externas, devem ser priorizados os cheios aos vazios. Assim existe esta limitação com referência ao tamanho das transparências na fachada. Inicialmente os portões das fachadas para as duas ruas iriam ser portões de madeira. A partir da relevância dos elementos descobertos no sítio que estão à mostra no térreo, surgiu o interesse de proporcionar ao pedestre, também pela noite, a possibilidade de ver livremente o interior. A proposta do vidro vem ao encontro da ideia de evitar barreiras visuais quando o passeio está fechado. Até o ultimo momento os arquitetos insistiram com esta proposta. Pensaram nos portões como uma barreira física que possibilitasse 
a segurança noturna do passeio e das unidades habitacionais, com o vidro garantindo a fluidez visual que o material proporciona. Sensível ao objetivo proposto de integrar o percurso do passeio à malha urbana da cidade os órgãos responsáveis, pela análise do projeto, observaram que era realmente interessante esta possibilidade. Desta forma com a iluminação noturna do passeio, as pessoas que circulam pelas ruas conseguem perceber o seu interior (Figura 09).

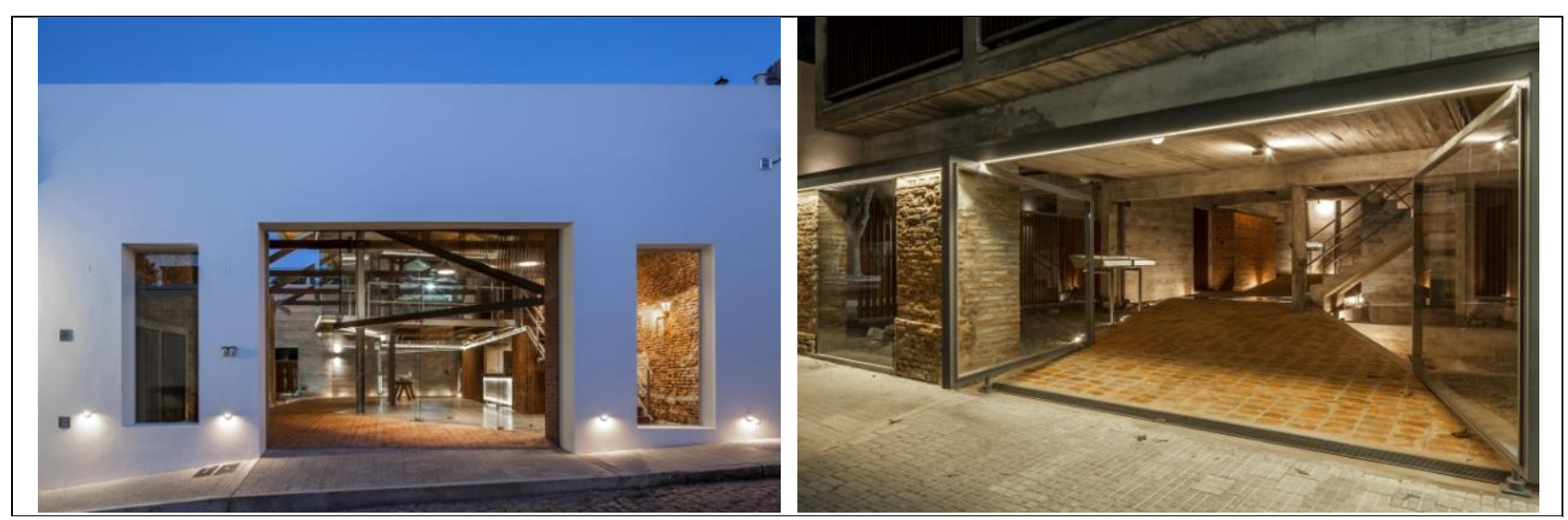

Fig. 09: Transparência e fluidez visual nas duas fachadas.

(Federico Kulekdjian para FRAZZI ARQUITECTOS)

\subsection{A arquitetura proposta}

O detalhe e o todo permeia a percepção do pedestre no seu trajeto. Como resultado tem-se uma arquitetura quase minimalista e crua, com materiais a vista, com uma qualidade de encontros que proporcionam uma certa leveza ao projeto. A experiência de intervir no Casco Histórico de Colônia do Sacramento como um Patrimônio da Humanidade surgiu da parceria entre os vários agentes envolvidos. Era esperado da proposta um espaço arquitetônico diferenciado com uma maior valorização da qualidade dos espaços gerados. Desde o princípio a opção não foi por um maior rendimento do empreendimento, do ponto de vista imobiliário. Este fato pode ser percebido no estudo realizado para chegar à tipologia das oito unidades habitacionais, pensadas inicialmente para dois tipos de usuários. Primeiramente para uma residência ocasional, por dois ou três meses por ano (fato bastante comum em Colônia) e num segundo caso também para uma moradia contínua. Numa planta se opta por um ambiente único o que de forma alguma deixa de lado a qualidade do espaço construído, seja pela preocupação com o conforto ambiental ou pelas generosas varandas. Percebe-se que o propósito principal é que estes unidades se nutram do exterior, cabendo recordar a localização do projeto, um sítio de singular valor patrimonial seja ele arquitetônico, histórico ou natural. As ventilações cruzadas e os pátios por vezes duplos retratam esta intenção garantindo uma boa vinculação entre exterior e interior. Para isso foram projetadas grandes portas janelas que se abrem e permitem uma visão fluida. A partir de estas duas tipologias iniciais, surgem os cubos ou caixas, módulos dispostos em diferentes situações acompanhando a topografia do terreno (Figura 10).

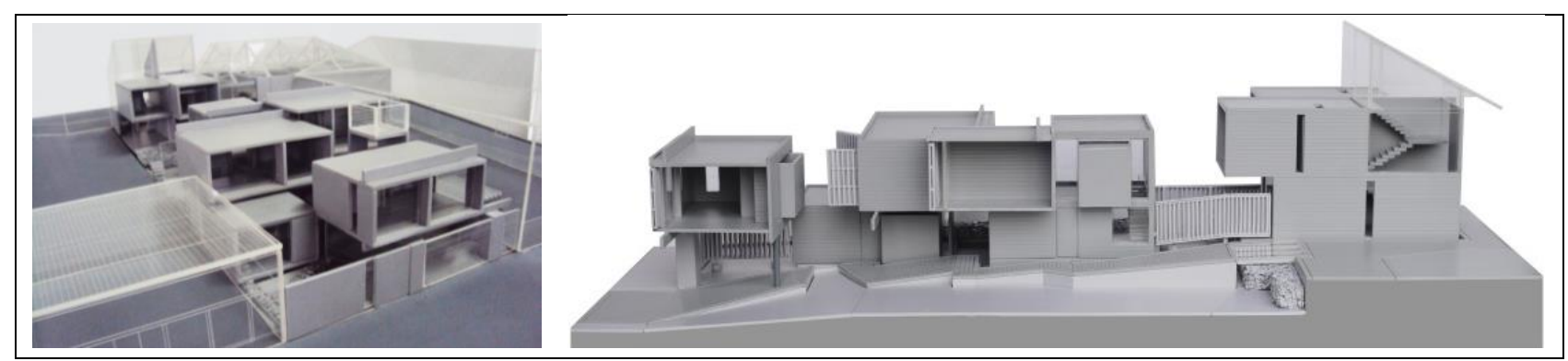

Fig. 10: Maquetes mostrando o movimento dos cubos acompanhando a inclinação dos lotes.

(FRAZZI ARQUITECTOS, Arq. Matías Frazzi)

Assim o resultado arquitetônico com o movimento destas caixas, que vão gerando por sua vez diferentes situações espaciais, vem a dialogar com a intervenção na malha urbana. Os terraços surgem em diferentes níveis onde se pode manter um contato visual com o rio. Foi realizado um estudo morfológico das duas ruas antes mesmo de considerar a intervenção como uma unidade. Na fachada voltada para a Rua Rivadavia (Figura 11-A) é possível observar a preocupação num diálogo com a escala de seu entorno. Desta forma a arquitetura proposta respeita o espaço patrimonial e suas tipologias. 


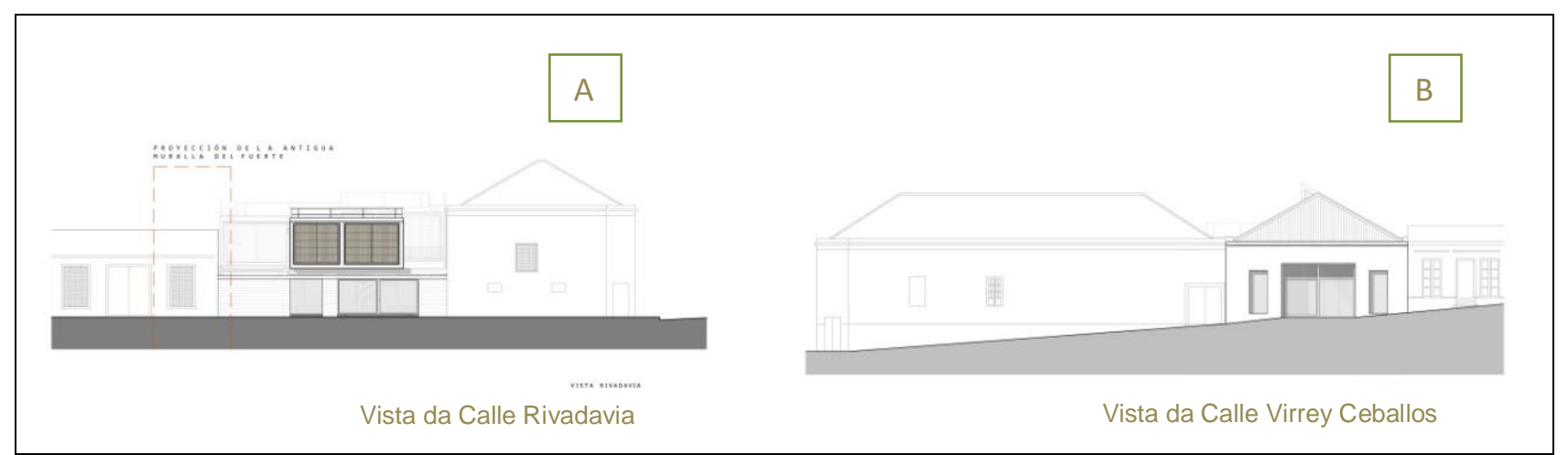

Fig. 11: Vistas dos dois acessos para a galeria interna.

Elaboração própria a partir das plantas do escritório FRAZZI ARQUITECTOS (Arq. Matías Frazzi)

Já na fachada da Rua Virrey Ceballos além de considerar a escala se percebe o empenho em resgatar e evidenciar a edificação existente (Figura 11-B), de caráter industrial com muros autoportantes de tijolos (Intendencia Municipal de Colonia, 2006:Padrón 242), já que sua manutenção era um condicionante. O edifício apresenta uma estrutura generosa em madeira bruta, o que sugeriu desde o primeiro contato com o sítio, tirar partido da construção, pela sua linguagem arquitetônica. Conservou-se a estrutura e num setor não foram colocadas as chapas para garantir a iluminação natural e a ventilação do passeio gerando uma situação ambiental mais rica. Foi conservada toda a estrutura, mas como as telhas de metal não eram as originais e não cumpriam sua função de vedar a cobertura, foram todas trocadas. Melhorou-se a estrutura, se reconstituiu então a cobertura e as chapas que estavam do lado externo, foram viradas e usadas como forro. Assim a espacialidade interna do café reflete um pouco este espírito da atividade do galpão. Com o uso de cheios e vazios, a proposta proporciona ao pedestre um trajeto diferenciado produzindo uma diversidade de sensações espaciais. O projeto procura tirar proveito do aspecto industrial da construção na saída para a Rua Virrey Ceballos (Figura 12). Para conservar a amplitude do espaço gerada pela cobertura, nos módulos acrescidos foram usados materiais como o aço (na estrutura) e o vidro (vedação) para manter a percepção de um pé-direito alto dando leveza a intervenção e imponência à construção existente.
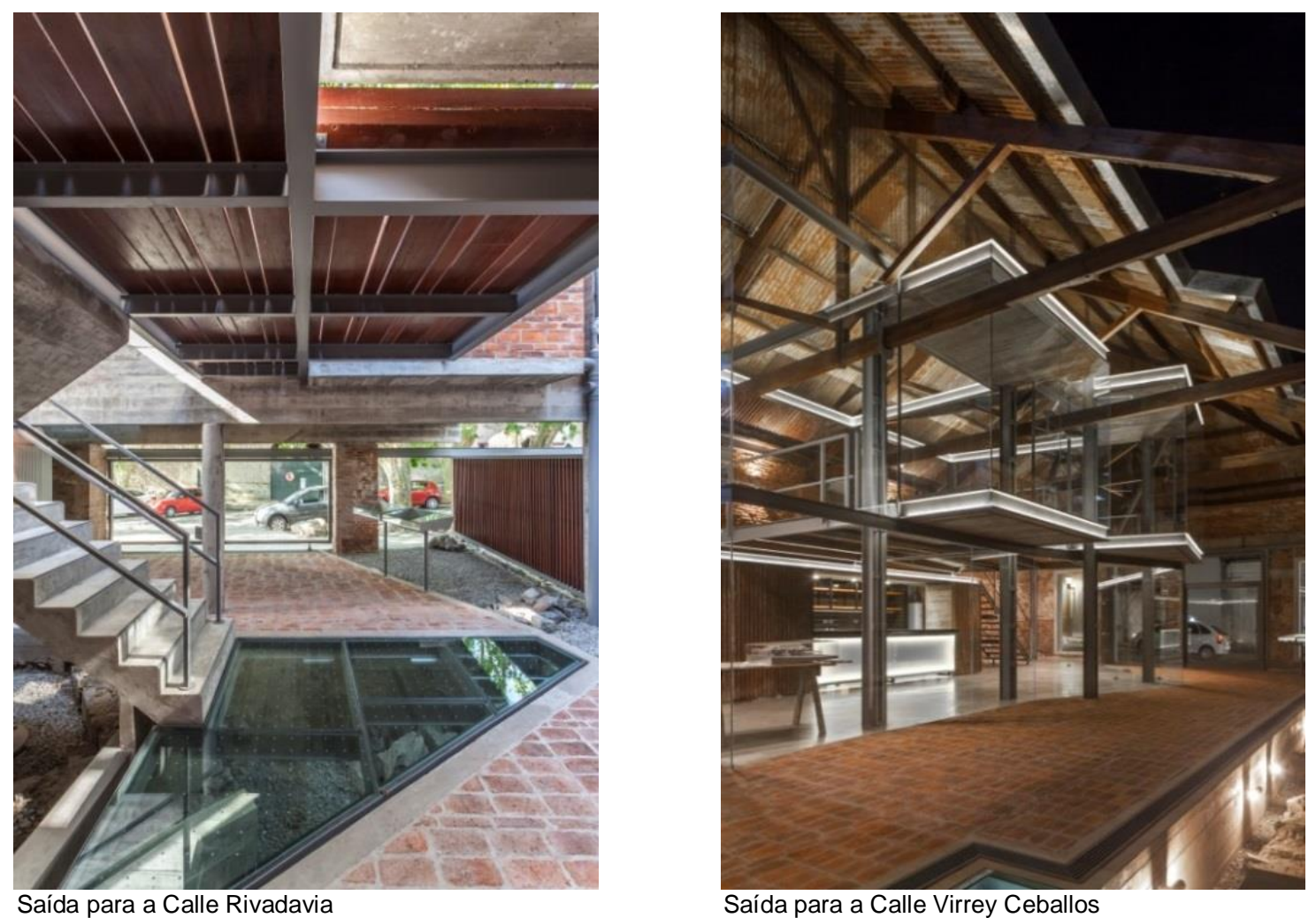

Fig. 12: Diferentes linguagens.

(Federico Kulekdjian para FRAZZI ARQUITECTOS) 


\section{CONCLUSÃO}

O arquiteto Matías Frazzi (2018) salientou o privilégio que foi intervir em um casco histórico com o reconhecido valor universal, como é o caso do Bairro Histórico de Colônia do Sacramento. É perceptível seu entusiasmo quando se refere ao projeto que sob sua perspectiva, lembrou os exercícios feitos na universidade. As condicionantes foram vistas como um desafio que enriqueceram a proposta do projeto. Resolver esta intervenção urbana arquitetonicamente e construtivamente de acordo com as normativas da Oficina do Patrimônio e da UNESCO exigiu uma análise mais profunda do contexto patrimonial. Para isto o trabalho com uma equipe multidisciplinar permitiu desenvolver um projeto de arquitetura mais abrangente. Ainda podemos somar às particularidades desta intervenção a liberdade criativa que o cliente confiou à equipe. Neste sentido é necessário destacar o reconhecimento outorgado pelo "10ํㅜ Premio Internacional Dedalo Minosse" ao projeto Paseo de La Brecha. Esta premiação defende a ideia de que para criar boas soluções arquitetônicas não basta ter uma qualidade de projeto por parte do arquiteto. Neste sentido o prêmio vem a valorizar também o cliente como, no caso desta intervenção, um gerador de cultura. Com um térreo ativo, aonde o Café surge como a única atividade comercial. Criando uma relação com a rua, o passeio convida o pedestre a entrar no percurso para visitar o sítio arqueológico. Indo na contra mão da estratégia contemporânea de muitas cidades que criam um edifício "ícone" onde no entorno dele gravitaria uma vida cotidiana. O projeto Paseo de La Brecha busca uma conexão com a cidade, com uma proposta clara de continuidade do espaço público. Não se restringe ao edifício como um novo elemento sobreposto ao contexto patrimonial. Ao mesmo tempo em que o projeto propõe uma ruptura da malha original ele sugere por meio de uma linguagem contemporânea uma conexão com o passeio que induz uma "galeria" num diálogo conceitual com o sítio onde está inserido. As condicionantes do projeto, por vezes muito rigorosas, fazem com que a equipe trabalhe com questões primordiais que podem servir de exemplo para outras intervenções. Isso foi metodologicamente contrário aos edifícios "icônicos" que pouco se relacionam com a carga histórica que os circundam. O projeto de La Brecha se mostra como um objeto urbano, uma arquitetura do século XXI, que se preocupa com a cidade. Com o amembramento dos lotes se cria o passeio que vem a gerar uma nova estrutura urbana distinta da estrutura inicial. Esta ruptura mostra 0 "contemporâneo" na malha urbana, criando uma nova dinâmica no espaço urbano. Assim se recordam os princípios do arquiteto Miguel Ángel Odriozola Odriozola, que defendia uma cidade "viva". É necessário perceber a possibilidade que projetos como este vislumbram, de qualificar o espaço urbano para fugir do perigo que a cidade corre de estar preso a apenas uma atividade econômica, o turismo. Buscou-se que o viajante enxergue a cidade viva e suas particularidades que a distinguem mesmo num contexto universal. As negociações acabaram interferindo tanto na escala do objeto como no espaço urbano. O novo circuito proposto intra-lote, que tira proveito do desnível topográfico entre os dois acessos, se integra ao percurso original das sinuosas ruas e vielas, herança do urbanismo português em seu desenho acolhedor ao pedestre.

\section{BIBLIOGRAFIA}

ARGAN, G. C. (1993). História da arte como história da cidade. São Paulo: Martins Fontes.

BARRETTO, M. (2007). Turismo y cultura. Relaciones, contradicciones y expectativas. Revista Pasos. Tenerife: Asociación Canaria de Antropología.

BETHELL, L. (org.) (1997). A América Latina Colonial Vol.1. São Paulo: EdUSP; Brasilia, DF; Fun. Alexandre Gusmão.

CANCLINI, N. G. (2003). A globalização imaginada. São Paulo: lluminuras.

CHOAY, F. (2011). O Patrimônio em questão: antologia para um combate. Belo Horizonte: Fino Traço.

CORTESÃO, J. (1954). O território da Colónia do Sacramento e a formação dos estados platinos in Separata. Revista de História (São Paulo), 17.

DIAZ BUSCHIAZZO, M. (2016). Atlas de la antigua Colonia del Sacramento. Montevideo: Tradinco.

FALERO, A. y CAMPODÓNICO, R. (comps.) (2014). El turismo bajo la lupa académica. Montevideo: Ediciones Universitárias. 
FRAZZI, M. (2018). Entrevista I. Entrevistadores: Maria Inés Travieso Rios e Luiz Eduardo Teixeira.1 arquivo .mp3 (127 minutos).

FUSCO, N. (1995). La arqueologia urbana em la Colonia del Sacramento. Revista do Museu de Arqueologia e Etnologia (São Paulo), 5, 39-49.

GIRALDI, A. (2018). Discurso de apresentação do livro Guía - Patrimonio Arquitectónico y Urbano del Barrio Histórico de Colonia del Sacramento do Arquiteto Miguel Odriozola, na FADU-UdelaR. Montevideo. (Arquivo cedido pelo autor).

GUTIÉRREZ, R. (1989). Arquitetura latino-americana. São Paulo: Nobel.

IMC, Intendencia Municipal de Colonia. Inventário Básico del Património Arquitectônico y Urbanístico del Barrio Histórico de Colonia del Sacramento. Ciudad de Colonia del Sacramento. Noviembre 2005/ Noviembre 2006.

LARRIQUETA, D. (1996). La Argentina Imperial. Buenos Aires:Editorial Sudamericana.

PGBHCS, Plan de Gestión del Barrio Histórico de Colonia del Sacramento. Intendencia de Colonia, Ministerio de Educación y Cultura Uruguay y Comisión del Patrimonio Cultural de la Nación. Enero de 2012.

SANTOS, M. (2010). Ensaios sobre a Urbanização Latino-Americana. São Paulo: Editora da Universidade de São Paulo.

WAISMAN, M. (2013). O interior da história: historiografía arquitetônica para uso de latino-americanos. São Paulo: Perspectiva.

SCIRGALEA, S. R. (2015). La Modernización em Colonia: apogeo y declive de la classe comerciante. Colonia del Sacramento.

\section{Fontes Eletrônicas}

AGN. Archivo General de la Nación. Decreto do governo de Gabriel Antonio Pereira de 20 de julio de 1859. http://www.agn.gub.uy (Consulta: 09/10/2017).

AMÁNDOLA, Duilio. (2012). Teoría y Crítica de la Arquitectura el Urbanismo y el Paisaje - De Colonia del Sacramento a Colonia. Arquitectura Panamentircana. http://arquitecturapanamericana.com/de-colonia-delsacramento-a-colonia/ (Consulta: 14/09/2017).

ODRIOZOLA GUILLOT, M., PAMPILLÓN. A., ARRICAR, J. y REINANTE, L. (2011). El Barrio Histórico de Colonia del Sacramento. Colonia del Sacramento.

http://www.sau.org.uy/content/Colonia Barrio Historico.pdf (Consulta: 12/01/2018).

JDC- Junta Departamental de Colonia. Acta de Sesiones de la Junta Econômica - Administrativa de Colonia. https://juntacolonia.gub.uy/index.php/component/content/article/56-legislacion/nomenclator/312intendente-suarez-y-florida-derogada-colonia-del-sacramento (Consulta: 11/10/2018).

MTU. Ministerio do Turismo do Uruguay. Turismo Receptivo - datos del tercer Trimestre (2017). http://mintur.gub.uy/index.php/component/idownloads/send/4-2017/71-tercer-trimestre-2017 (Consulta: 12/01/2018).

MALHE, A. y REITANO, E. (comps.) (2008). Pensar Portugal: Reflexiones sobre el legado histórico y cultural del mundo luso en Sudamérica [em línea]. La Plata: Universidad Nacional de La Plata, Facultad de Humanidades y Ciencias de la Educación. Disponible en:

http://www.fuentesdememoria.fahce.unlp.edu.ar/libros/pm.285/pm.285.pdf (Consulta:25/10/2017).

PÉREZ, L. C. (2011). Patrimonio y Arqueología en la región platense. Montevideo: Universidad de la República, Facultad de Humanidades y Ciencias de la Educación. Disponible en: https://www.colibri.udelar.edu.uy/bitstream/123456789/4482/1/FHCE Cabrera 2011-06-15 webO.pdf (Consulta: 16/06/2017). 
SANTOS, E. (2001). O povoamento da bacia platina durante o período colonial: a contribuição dos nortenhos. XII Congresso Internacional de AHILA, vol. III, Porto, Centro Leonardo Coimbra da Faculdade de Letras da Universidade do Porto. http://hdl.handle.net/10216/20740 (Consulta: 12/06/2017).

SCIRGALEA, S. R. Informe Histórico: Real de San Carlos.

https://www.academia.edu/24040027/Real de San Carlos (Consulta: 25/08/2017). 